\title{
The Effect of Using Group Work Technique on Students' Reading Comprehension at the First Year of Senior High School 4 Mandau
}

\author{
Annisa Tul Ulatifah \\ Universitas Islam Negeri Sultan Syarif Kasim Riau, Indonesia \\ Annisatululatifah15@gmail.com \\ Nuardi \\ Universitas Islam Negeri Sultan Syarif Kasim Riau, Indonesia \\ nuardi@uin-suska.ac.id
}

\begin{abstract}
This research was aimed to find out The Effect of Using Group Work Technique on Students' Reading Comprehension. The design of this research was quasi experimental. The population was the total of tenth grade students that consist of 10 classess. Meanwhile the sample was proportion of the population that consist of 2 classes. $X^{6}$ was experimental class and $\mathrm{X}^{9}$ was control class. The number of sample was selected by using cluster sampling. To analyze the data the writer gave pretest and posttest then analyzed the data by using independent sample t-test by using SPSS 16 version and effect size formula. After analyzing the data, where the 2-tailed value was smaller than $0.05(0.000<0.05)$. The result of effect size was 0.3 categorized as large effect. Thus, null hypothesis $\left(\mathrm{H}_{\mathrm{o}}\right)$ is rejected, and alternative hypothesis $\left(\mathrm{H}_{\mathrm{a}}\right)$ is accepted. So, it can be concluded that there was a significant effect of using Group Work Technique on Students' Reading Comprehension
\end{abstract}

Keyword: Effect, Group Work Technique, Reading Comprehension

\section{Introduction}

Reading is both process and product. It involves the interaction between the reader and the text - how the reader is deciphering the writing on the page, what the reader is thinking about while reading, and how the reader is monitoring his or her reading. (McKay, 2006, p. 224 : Alderson, 2000).

Reading is the most important skill because there are many sources of written information. By reading a lot, students may enlarge their vocabulary and will be more familiar with English sentence structure. When the students read, they also process and transfer information on their brain, so they must focus on reading comprehension.

Reading is useless without comprehension, According to Snow (2002, p. 11), reading comprehension is the process of simultaneously extracting and constructing meaning through interaction and involvement with written language. 
Based on the School-Based Curriculum, the aim of learning English is to develop the skills of language. Reading is one of the receptive skills. The standard competence of reading at the first senior high school is the students are able to find the meaning of essay text in report, narrative, descriptive, and recount text in daily life activities and access knowledge.

In this research, the writer is interested in improving students' reading competence in narrative text.

Narrative text is a text about telling a story which tells the conflicts among the characters and problems to be resolved by them. According to Wardiman et al (2008, p. 93), a narrative text is an imaginative story to entertain people. The writer used narrative text because the basic purpose of narrative text is to amuse or entertain the reader with its story and narrative itself as is included in the School Based Curriculum (KTSP).

SMA N 4 MANDAU is one of formal school located in Duri. This school uses School Based Curriculum (KTSP) as guideline to teach and learn English. SMA N 4 MANDAU has passing grade that student must follow, it is 75 . The students must achieve higher score than their minimum criteria of passing grade, it can help them finish evaluation. The students are demanded to more learn and much read individually to improve their ability. There is a big problem if they are not supported by the effective strategy in learning process. In teaching and learning process, especially in reading, students are expected to be able to comprehend the text by many ways. Usually, the teacher only used the same method every meeting. It was not overall, but there were some of the teachers who still used the old strategy. It means that there was no variety in learning process. And it made the students not interested in reading. Because it was a monotonous way. So, this condition made the students lose their spirit in learning process, and the worst possibility made the ability of understanding poor.

The teacher found the students had a lack of ability in finding the meaning of words and mentioning the detail information from generic structure of narrative text such as orientation, complication, and resolution and the students had difficulties in comprehending reading narrative text.

Based on the description above, not all of the students are interested in reading. They found difficulties in comprehending the text they read. Most of them only read the text but they did not understand what they read. The students were able to read fluently, but they could not get the meaning or the message from the text.

Based on the preliminary study at SMA N 4 MANDAU, especially at the second year, The writer found the following phenomena :

1. Some of students are not able to find out main idea of narative text.

2. Some of students are not able make inference of narrative text.

3. Some of students are not able to find out meaning of certain words of narrative text

4. Some of students are not able to identify generic structure of narrative text

5. Some of students are not able to locate or identify general or specific information such as names of characters, the time of the story or the place of the story in narrative text

6. some of students not have interest in reading narrative text 
Therefore, to solve this problem needs an appropriate technique to influence their reading comprehension. There are many techniques developed in teaching reading.

One of the techniques is group work. According to Brown (2001, p. 173), group work is a generic term covering a multiplicity of techniques in which two or more students are assigned a task that involves collaboration and self-initiated language.

Beside that group work can motivate the students read because they work together so that they can share their opinions and understanding about the texts given with their friends. Because of that reason, the writers want to offers Group Work technique. The teacher can apply the strengths of group work to reach constructive solutions on improving reading comprehension.

In this paper, the writers want to discuss about the effect of using group work technique on students' reading comprehension at first year of SMA N 4 Mandau Duri-Riau.

\section{Literature Riview}

Nunan states in Zain thesis (2012, p. 16) that group work is essential to any classroom that is based on principle of experiential learning. He adds that through group work, learners develop their ability to communicate through tasks that require them, within the classroom, to approximate the kinds of things they will need to be able to do communicate in the world beyond the classroom. Thus, communication in the classroom can be aroused among the students through group work.

Supporting Nunan's idea, Brown (2001, p. 173) states "group work as a generic term covering a multiplicity of techniques in which two or more students are assigned a task that involves collaboration and self-initiated language.

"He adds that gruop work usually implies "small" - group work, that is, students in groups of perhaps six or fewer. Thus, there is a basic concept about group work according to Brown. Group work has two key points related to the teaching and learning process. They are groups's member and collaboration to carry out a task.

In summary, group work is a kind of technique in language learning where students collaborate with other students and initiate him/her in doing language learning activities. The number of students in a small group is six or fewer. The appropriate number of the group can influence the implementation of group work task in the classroom.

According to many writers, group work has many advantages for English language classroom. Brown (2001, pp. 173-174) points out a number of the advantages of group work such as "it generates interactive language, offers an embracing effective climate, promotes step toward individualizing instruction."

In the English learning and teaching context, Harmer (2004, p. 166) asserts some advantages of group work as presented below.

1) "It dramatically increases the amount of talking for individual students.

2) Because there are more than two people in the group. Personal relationships are usually less problematic; there is also a greather chance of different opinions and varied contribution than in pair work.

3) It encourages broader skills of cooperationand negotiation than pair work, and yet is more private 
than work in front of the whole class.

4) It promotes learner autonomy by allowing students to make their own decision in the group without being told what to do by the teacher.

5) Some students can choose their level or participation more readily"

In summary, group work has a number of benefits for language learning and teaching. Firstly, group work is good to be conducted because it can generate interactive language. Secondly, students can convey and receive ideas and also negotiate meaning during the lesson. Thirdly. it also offers an embracing affective climate that can increase students' motivation. Fourthly, in promoting learner autonomy, group work can be a solution in the English learning and teaching process. By considering that the students has their own language ability, group work can bridge this issue and it can be one way to overcome the problem faced by the language teachers.

Brown (2001, p. 179) asserts that the first step in promoting successful group work is to select an appropriate task. In other words, choose something that lends itself to the group work process. He also proposes kinds of group work activities which are appropriate to be implemented in a classroom such as games, role-play and simulation, drama, projects, interview, brainstorming, information gap, jigsaw, problem solving and decision making, and opinion exchange.

Furthermore, according to Brown (2001, pp. 173 - 174) the procedures of using Group Work Technique as follows:

a. The teacher mentions the objectives and the goals of the study which are stated in the lesson plan and also do some triggering activities.

b. The teacher devides the students into some groups that consist of 4 persons of each group. There will be one captain in each group that will leads the other members in the process.

c. The teacher explains how group work is to the students; what they are going to do in the activity, and distribute the Narrative story.

d. The teacher models the activity at the first before the students do it in their group.

e. The students work out with the story in their group

f. The teacher helps the students if there is something they do not understand.

\section{Research Method}

\section{a. Design of the Research}

This research was quasiexperimental research. Creswell (645, p. 2008) states that "quasi-experiments are experimental situations in which the researcher assigns, but not randomly, participants to groups because the experimenter cannot artificially create groups for the experiment. The writer used intact groups, the first class was as the experimental group and the second class was as the control group. Gay (394, p. 2000) also states that quasiexperimental design is not possible to randomly assign individual participants to groups in several cases.

This research involved two groups; they were control group and experimental group. Both of classes would be given pre-test and post-test. Meanwhile the experimental class 
would be treated by using Round Table technique but the control class was not.

The research was conducted at the first year students of SMA $\mathrm{N} 4$ MANDAU. This research was conducted from April to May 2017. The subject of this research was the first year students of SMA N 4 MANDAU, and the object of this research was the effect of using group work technique students' reading comprehension of Narrative text.

The population of this research was the the first year students of SMA N 4 MANDAU in 2016-2017 academic year. It had 10 classes. The total number of the first year students at SMA N 4 MANDAU was 325 students. The writer selected two classes to be taken as samples. The writer took sample by using cluster random sampling. According to Gay (2000, p. 29 ), cluster random sampling is most useful when the population is very large or spread out over a wide geographic area. So, the writer used cluster random sampling which selected groups, not individuals.

Cluster random sampling is most useful when the population is large on spread out over a wide geographic area. Based on explanation above, to find the sample, the writer used lottery by passing out small rolled paper marked by sequence name of the class. Then after passing out the paper, the samples of this research were $X^{6}$ as experimental class and $\mathrm{X}^{9}$ as control class. Those were as the sample of the research by number 60 students.

The test was divided into two test; pre-test and post-test. Pre test was given before treatment. The test was administered to class $\mathrm{X}^{6}$ as experimental class and class $\mathrm{X}^{9}$ as control class. Post- test was given after teaching several time, it was given for both of the classes.
In order to see whether there was the effect of using Group Work Technique on students' Reading Comprehension, the writer used independent sample t-test through SPSS 16 version and effect size formula.

\section{b. Technique of Collecting Data}

The writer collected the data by using test. The test was written test and the type was multiple choice. There were five indicators of reading comprehension; each indicator was represented by five questions, so the total number of the test was twenty five items. This test was given to both of the control class and experiment class before each class was given the treatment.

Then the writer assessed the normality of data by using kolmogorovsmirnov test from SPSS 16 version. After analyzing, the data was normal because sig. values were higher than $0.05(0.200>0.05)$ and $(0.180>$ $0.05)$.

\section{c. Technique of Analyzing the Data}

The data of this research was the scores of students' test of both experiment and control classes. The main purpose of the research was to explore the effect of using Group Work Technique on students' Reading Comprehension. The students' test was analyzed by using quantitative data analysis for the findings.

Both descriptive and inferential statistical analyses were included. Frequency counts, percentages, mean scores and standard deviation of the variables were presented in the descriptive statistical analyses. The hypotheses developed for this study were tested by using effect size. 


\section{Research Finding}

In this research, the data were analyzed by using a statistic software of Statistical Product and Service Solutions (SPSS) 16 version. The result of t-test analyzing could be seen on the SPSS output.
To explain more about the posttest score of experimental class and post-test score of control class consisting of 60 participants at State Senior High School 4 Mandau, the writer described it in the following table which was obtained from the output of SPSS 16.

The Descriptive Statistics of Post-test Experimental Class and Control Class

\section{Group Statistics}

\begin{tabular}{|ll|c|c|c|c|}
\hline & GROUP & $\mathrm{N}$ & Mean & Std. Deviation & Std. Error Mean \\
\hline SCORES & POSTTEST & 30 & 76.53 & & 7.482 \\
& EXPERIMENT & 30 & 66.00 & 9.613 & 1.366 \\
& POSTTEST CONTROL & 30 & 1.755 \\
\hline
\end{tabular}

Based on the table above, the total number of students in experimental class consisted of 30 students and in control class 30 students. The mean of experimental class was 76.53 and the mean of control class was 66.00 , while standard deviation of experiment class was 7.482, while control class was 9.613. The std. error of mean of experimental class was 1.366 , while control class was 1.755 . Thus, the majority of the students in experimental class after being taught by using Group Work Technique were classified as Good. Meanwhile the majority of the students in control class after being taught without using Group Work Technique were classified as Good.

Based on the result of independent sample t-test by using SPSS 16 version, it could be seen that $t_{0}>$ $t_{\text {table. }}$. Where $\mathrm{df}=58$, it was found the level significance of 5\% was 2.01 and the level significance of $1 \%$ was 2.68. The data showed that $t_{\text {observe }}$ was higher than $\mathrm{t}_{\text {table }} ; 2.01<4.736>2.68$. it means that null hypothesis (Ho) was rejected, while alternative hypothesis (Ha) was accepted.

To identify the level of the effect of Group Work Technique on students' Reading Comprehension at The First
Year of Senior High School 4 Mandau, the writer calculated by using eta squared formula.

Based on the result finding, it was clear that the effect size was 0.3. Furthermore, Pallant (2010 : 210), the guidelines for inteprenting this value are $0.01=$ Small effect, $0.06=$ medium effect, 0.014= Large effect.

The result of effect size was 0.78 categorized as large effect. It means that there was a significant effect between students' reading comprehension taught by using and without using Group Work Technique at The First Year of Senior High School 4 Mandau.

\section{Discussion}

Pertaining to the explanation above, this research showed that the students' Reading Comprehension taught by using Group Work Technique at The First Year of Senior High School 4 Mandau was categorized into good level.

The students' Reading Comprehension taught without using Group Work Technique at The First Year of Senior High School 4 Mandau was categorized into good level. 
Ha was accepted because of the result $2.01<4.736>2.68$. and the result of effect size was 0.3 categorized as large effect. It means that there was a significant effect between students taught by using and without using Group Work Technique at The First Year of Senior High School 4 Mandau.

\section{Conclusion}

Based on the research finding above, it could be concluded that in teaching Reading by Using Group Work Technique at The First Year of Senior High School 4 Mandau was better than without using Group Work Technique. Thus, there was a significant effect between the students taught by using and without using Group Work Technique at The First Year of Senior High School 4 Mandau.

\section{References}

BSNP. 2006. Standard Isi Untuk Satun Pendidikan Dasar dan Menengah Standar kompetensi dan kompetensi Dasar SMA/MA. Jakarta:BSNP.

Brown, H. D. 2001. Teaching by Principle. An Interactive Approach to Language Pedagogy. ( $4^{\text {th }}$ ed) New York: Longman.

Creswell, John W. 2008. Educational Research: Planning Conducting and Evaluating Quantitative and Qualitative Research. New Jersey: Pearson Education Ltd.

Department of National Education. 2006. Syllabus of English For Senior High School.

Gay, L.R \& Peter Airasian. 2000. Educational Research Competencies for Analysis and
Application. Six Ed. New Jersey: Prentice-Hall.

Harmer, J. 2004. The Practice of English Language Teaching. $\left(4^{\text {th }}\right.$ ed) London: Longman.

Kurnia H. Nurlatifah Zain. 2012. The effect of using group work on reading Comprehension for the students of the eighth grade of smpn 1 cangkringan in the academic year of 2011/2012. Yogyakarta: Unpublished Thesis.

McKay, Penny. 2006. Assessing Young Language learners. London: Cambridge University Press.

Pallant, Julie. 2005. SPSS Survisal Manual. Sydney: Ligare.

Snow, Catherine E. 2002. Reading for Understanding : toward A research and Program in Reading Comprehension. Arlington, VA : RAND.

Wardiman, Masduki B. Jahur, and M. Sukirman Djusma. 2008. English in Focus 2: for Grade VIII Junior High School (SMP/MTs). Jakarta: Pusat Perbukuan, Departemen Pendidikan 